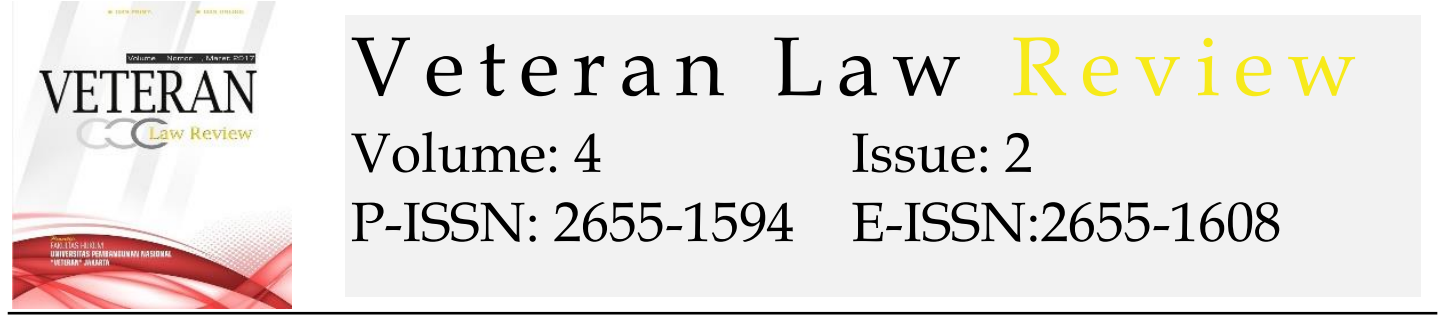

\title{
Restorative Justice Approach in Crime of Humiliation Through Social Media
}

\author{
Beby Suryani Fithri ${ }^{1}$, Windy Sri Wahyuni ${ }^{2}$ \\ ${ }^{1}$ Faculty of Law, Universitas Medan Area, E-mail: bebysuryani07@gmail.com \\ ${ }^{2}$ Faculty of Law, Universitas Medan Area, E-mail: windy@staff.uma.ac.id
}

\begin{tabular}{|c|c|}
\hline ARTICLE INFO & ABSTRACT \\
\hline $\begin{array}{l}\text { Keywords: } \\
\text { Restorative Justice, Crime } \\
\text { of Humiliation, Social } \\
\text { Media } \\
\text { Howw to cite: } \\
\text { Fithri, B. S., \& Wahyuni, } \\
\text { W. S. (2021). Restorative } \\
\text { Justice Approach in } \\
\text { Crime of Humiliation } \\
\text { Through Social Media. } \\
\text { Veteran Law Review. } 4(2) \text {. } \\
\text { 143 - 156. } \\
\text { Received: 2021-06-29 } \\
\text { Revised: } 2021-09-21 \\
\text { Accepted: 2021-10-22 }\end{array}$ & $\begin{array}{l}\text { The restorative justice approach is a diversion in the handling of } \\
\text { criminal acts which in the criminal justice procedure are centered on } \\
\text { imposing criminal sanctions which are transferred to a } \\
\text { communication and mediation process that presents the perpetrators, } \\
\text { victims, families of the perpetrators/victims, and other related parties } \\
\text { to come together to realize a form of agreement. for the handling of } \\
\text { criminal acts that are fair and proportional to the victims who are } \\
\text { harmed and the perpetrators by prioritizing repairs such as initial } \\
\text { conditions and restoring a harmonious interaction model in society. } \\
\text { It is this restorative justice approach that will be used in the } \\
\text { investigation, investigation and examination stages in courts of } \\
\text { insults, considering that the enforcement of criminal law against } \\
\text { insult cases that occur in the community has not given satisfactory } \\
\text { results. The regulation of defamation offenses whether carried out } \\
\text { offline or online with social media refers to the provisions of the } \\
\text { Criminal Code (KUHP) and the Information and Electronic } \\
\text { Transactions Law, which in these two provisions contain criminal } \\
\text { sanctions against the perpetrators. The purpose of the restorative } \\
\text { justice approach in dealing with insults offenses is the restoration of } \\
\text { victims who suffered as a result of the humiliation by providing } \\
\text { compensation, imposing social work on the perpetrators and matters } \\
\text { mutually agreed upon by the parties. }\end{array}$ \\
\hline
\end{tabular}

\section{Introduction}

Everyone basically has a human right to convey information using all available channels. These human rights are guaranteed in Article $28 \mathrm{~F}$ of the 1945 Constitution. However, the implementation of these rights is not a human right that cannot be reduced under any circumstances (nonderogable rights). The human rights regulated in Article 28F are derogable rights.

The Constitutional Court in its Decision Number 50/PUU-VI/2008 stated that although everyone has the right to communicate and obtain information, it does not eliminate the state's right to regulate that the freedom to communicate and obtain information does not violate the rights of others to obtain protection which is also guaranteed by the constitution. . 
In the current digital era, cases of defamation are found, especially through social media or other digital media. The Southeast Asia Freedom of Expression Network (SAFEnet) in the 2018 SAFEnet Annual Report noted that there were 292 decisions on ITE-specific criminal cases in 2018 according to the Supreme Court. Based on these data, the criminal act of defamation in Article 27 paragraph 3 of the ITE Law jo. Article 45 paragraph 3 of Law 19/2016 is the most reported case. Even from the 2019 Indonesia Digital Rights Situation Report, defamation (defamation) is the most common. ${ }^{1}$

Social media makes it easy for people to express and freely express their opinions. However, with the freedom and convenience, people often forget that in expressing and expressing opinions, one must maintain behavior and ethics in interacting through social media, especially electronic social media, thus triggering unlawful acts such as insults.

The offense of defamation is also known as defamation, which was originally an act of criticizing the good name and honor of another person who was not in the sexual sphere so that the person suffered losses. Honor and good name have different definitions, although the two cannot be separated from one another, because criticizing honor will have an impact on honor and tarnishing his name, as well as criticizing a good name will affect a person's good name and honor can be polluted. However, experts do not yet have the same opinion regarding the definition and limitations of honor and good name, but they agree that honor and good name are the rights of a person or human rights of every human being. ${ }^{2}$

As for the law enforcement steps for insulting offenses through social media, they are carried out after complaints from victims that an insult offense has occurred. In this case, it is the Police who are authorized to carry out investigations and investigations to be subsequently submitted to the prosecutor's office and forwarded to examination in court.

The Police, Prosecutors and Courts can provide opportunities for suspects and victims to settle disputes outside the court and/or make peace. In resolving disputes outside the court, the police can facilitate as a neutral third party to reach a peace agreement between the two disputing parties by applying a restorative justice approach.

Restorative justice is a form of a new approach model in the settlement of criminal cases. This restorative justice approach model has actually been used in several countries with a focus on its approach to perpetrators, victims

1 Erizka Permatasari .(2021). Penanganan Pencemaran Nama Baik di Medsos Harus Mengedepankan Restorative Justice. from website https://images.hukumonline.com/frontend/lt5f8445b8eca72/1t5f854ca34b378.png

2 Leden Marpaung, (2010). Tindak Pidana Terhadap Kehormatan, Jakarta: Sinar Grafika 
and the community in the process of resolving legal cases that occur between them. Although this approach model is still widely debated at the theoretical level by experts, in reality it continues to grow and exist and influences policy and legal practice in many countries.

Eva Achjani Zulfa stated that restorative justice is a concept of thought that responds to the development of the criminal justice system by focusing on the need for community involvement and victims who feel excluded from the mechanisms that work in the current criminal justice system. ${ }^{3}$

The restorative justice approach process is carried out with a policy so that there is a transfer of the criminal act settlement process outside the criminal court process and resolved through a deliberation process. Settlement through deliberation is actually not a new thing for Indonesia, even customary law in Indonesia does not distinguish between criminal and civil cases, all cases can be resolved through deliberation with the aim of getting a balance or restoration of the situation. ${ }^{4}$

In principle, restorative justice can be used at every stage of the criminal justice system and will be carried out properly, if it meets the requirements, namely; first, the perpetrator must confess or plead guilty; secondly, the victim party must agree that the crime is resolved outside the criminal justice system; third, the police or the prosecutor's office as an institution with discretionary authority must approve the implementation of restorative justice; and fourth, the implementation of settlements outside the criminal justice system must be supported by the local community. ${ }^{5}$

Law enforcement of defamation offenses through social media using a restorative justice approach is based on considerations of the philosophy of restorative justice itself. That restorative justice rests on a humane relationship between victims and offenders and focuses on the impact that crime has on all parties, not only the victims but also the community and the offenders themselves. The elements of restorative justice in sentencing are concession, mediation, reconciliation, healing, and forgiveness. These elements are different from the elements of retributive justice, namely retaliation, punishment, isolation, stigmatization and imprisonment. ${ }^{6}$

3 Eva Achjani Zulfa, (2009). Keadilan Restoratif, Jakarta : Badan Penerbit Fakultas Hukum Universitas

4 Barda Nawawi. (1996). Batas-Batas Kemampuan Hukum Pidana Dalam Penanggulangan Kejahatan, Makalah Seminar Nasional Pendekatan Non Penal Dalam Penangulangan Kejahatan, Semarang : Graha Santika Hotel

5 Zaidan, M. A. (2015). Menuju Pembaharuan Hukum Pidana. Jakarta: Sinar Grafika

6 Teguh Prasetyo \& Abdul halim Barkatullah. (2005). Politik Hukum Pidana Kajian Kebijakan Kriminalisasi dan Dekriminalisasi, Yogyakarta : Pustaka Belajar 
Based on this background, the focus of the discussion in this paper is on how to regulate the law for insulting offenses in Indonesia and how to approach restorative justice in insulting offenses through social media.

\section{Method}

Method is a process, principles and procedures for solving a problem while research is a careful, diligent and thorough examination of a phenomenon to increase human knowledge, so research methods can be interpreted as a process of principles and procedures for solving problems encountered in conducting research. ${ }^{7}$ Legal research is a process to find the rule of law, legal principles, and legal doctrines in order to answer the legal issues faced. ${ }^{8}$ This type of research is normative juridical research. Normative Juridical Approach, namely research that is focused on examining the application or rules or norms in positive law.

In this study obtained through secondary data, namely data collected through document studies of library materials. The search for legal materials is carried out by reading, viewing, listening, or by searching for legal materials using the internet. ${ }^{9}$ The data analysis used in this study is qualitative data analysis, where the data collected is not in the form of numbers that can be measured. However, based on laws and regulations, as well as information views to answer the problems of this research. Conclusions are drawn deductively, namely thinking starting from the general to the specific. ${ }^{10}$

\section{Regulation Of Humiliating Crime In Indonesia}

R. Soesilo stated that humiliation is an act of attacking someone's honor and reputation. Those who are attacked are usually ashamed, the honor that is attacked here is not honor in the sexual field. ${ }^{11}$

Humiliation has long been a part of Indonesian criminal and civil law, because basically Indonesia inherited the legal system that prevailed during the Dutch East Indies era. The law of humiliation in Indonesia is basically regulated in 2 (two) major groups, namely the criminal law group which is

7 S Soekanto, (1995). Penelitian Hukum Normatif Suatu Tinjauan Singkat, Jakarta: Raja Grafindo Persada

8 Peter Mahmud Marzuki. (2010). Penelitian Hukum, Jakarta : Kencana

9 Mukti Fajar ND and Yulianto Achmad. (2010). Dualisme Penelitian Hukum Normatif \& Empiris. Yogyakarta : Pustaka Belajar

10 Syamsul Arifin. (2011). Falsafah Hukum. Medan : Uniba Press

11 R, Soesilo. (1996). Kitab Undang-Undang Hukum Pidana Serta Komentar-Komentar Lengkap Pasal Demi Pasal. Bogor : Politeia 
regulated in the Criminal Code and several other laws which also contain provisions of several articles. ${ }^{12}$

Legal arrangements regarding defamation offenses can be found in the Criminal Code (KUHP) and the ITE Law. The distinction in the formulation of this rule is based on the widening of the facilities or instruments used in carrying out insults. Defamation offenses in the Criminal Code are still simple/conventional when faced with the ITE Law which has utilized electronic instruments or media in this case social media.

The offense of defamation is basically found in the Criminal Code (KUHP) Book two of Chapter XVI concerning Criminal Acts of Honor or humiliation. The types of insulting offenses found in the Criminal Code are:

1. Insulting through words/speech.

Verbal insult is found in article 310 verse 1 which reads:

"Whoever intentionally/intentionally threatens the honor or reputation of a person by accusing him of committing a particular act, with the clear intention of disseminating the accusation to the public, shall be punished for his negligence in insulting with a maximum imprisonment of nine months or a maximum fine of four thousand five hundred rupiah "

2. Insulting through writing

Insulting through writing is found in article 310 verse 2 which reads:

"If this is done with a letter or picture that is distributed, displayed or affixed, then the perpetrator for his forgetfulness insulted through the letter, sentenced to imprisonment for a maximum of one year and four months or a maximum fine of four thousand five hundred rupiah"

3. Defamation

Defamation through writing is found in article 311 which reads:

"(1) Whoever makes insult or defamation by letter, in the event that he is allowed to show evidence of the accusation is punishable for defamation with a maximum imprisonment of four years, if he is unable to show the evidence and if the accusation he launches is found to be untrue"

4. Mild insults

Mild insults through writing are found in article 315 which reads:

"Any intentional/unintentional insult or insult by letter, made against a person either in public orally/speech or by letter either in front of the person

12 Gomgom TP Siregar. (2020). Suatu Analisis Mengenai Tindak Pidana Pencemaran Nama Baik Melalui Media Elektronik. Bandung : Refika Aditama 
himself by word of mouth or action, either by letter delivered or delivered to him, was sentenced for negligence of minor insult, with imprisonment for a maximum of four months and two weeks or a maximum fine of three hundred rupiah."

\section{Defamation announcements}

Defamation announcements through writing are found in article 317 which reads:

“(1) Whoever intentionally brings or orders to record a letter of complaint or false announcement letter about a person to a public official, so that the honor or reputation of that person is threatened, shall be punished for defamation by complaint with imprisonment for a maximum of four years.

(2) Revocation of the rights contained in Article 35 numbers one to three may be imposed."

6. False allegations

False allegations through writing are found in article 318 which reads:

"Whoever intentionally commits an act, causing someone to falsely become a suspect in committing a criminal act, shall be punished for slandering with an act with a maximum imprisonment of four years"

7. Insulting the dead.

Insulting people who have died through writing is found in articles 320 and 321 which read:

Article 320

"Whoever commits an insulting act against a deceased person or insults him by letter, for example he is still alive, shall be sentenced to a maximum imprisonment of four months and two weeks or a maximum fine of three hundred rupiahs."

Article 321

"Anyone who announces, shows or attaches a letter or picture whose content insults or insults a deceased person, with the aim that the contents of the letter or picture are seen by the public or more by the public, shall be punished with imprisonment for a maximum of one month and two weeks or a fine of a maximum of three months. hundred rupiah."

Meanwhile, the regulation of defamation offenses based on the Electronic Information and Transaction Law is found in article 27 paragraph 3 which reads: 
"Every person intentionally and without rights distributes and/or transmits and/or makes accessible Electronic Information and/or Electronic Documents that have insulting and/or defamatory content."

Furthermore, the threat of punishment for someone who does not comply with the provisions of Article 27 paragraph (3) of the ITE Law is found in Article 45 paragraph 3 which reads:

"Every person who knowingly and without rights distributes and/or

transmitting and/or making accessible Electronic Information and/or Electronic Documents containing insults and/or defamation as referred to in Article 27 paragraph (3) shall be subject to a maximum imprisonment of 4 (four) years and/or a maximum fine of IDR 750,000,000.00 (seven hundred and fifty million rupiah)."

Based on the regulation of the insulting article above, it can be analyzed that in UUITE 2008 insult/defamation is an ordinary offense so that it can be processed legally even if there is no complaint from the victim. However, by referring to the Criminal Code as intended by the 2016 UUITE, the offense turns into a complaint offense (klacht delic) which requires the victim to make a complaint to the authorities. The content of the explanation norm of Article 27 UUITE 2016 indirectly adopts the considerations of the Constitutional Court Decision Number 50/PUU-VI/ 2008 in conjunction with the Constitutional Court Decision Number 2/PUU-VII/2009.

In consideration of the Constitutional Court Decision 50/PUU-VI/2008 it is stated that the validity and interpretation of Article 27 paragraph (3) of the ITE Law cannot be separated from the basic legal norms in Article 310 and Article 311 of the Criminal Code as a genus of delict which requires a complaint (klacht) to can be prosecuted, must also be treated against acts prohibited in Article 27 paragraph (3) of the ITE Law, so that Article a quo must also be interpreted as an offense requiring a complaint (klacht) to be prosecuted before the Court.

\section{Restorative Justice Approach To Enforcement Of Humiliating Crime Through Social Media}

Social media is a medium to socialize with each other and is done online which allows every human being to interact with each other without being limited by space and time. However, the fact is that there is a deviation in the use of social media. Social media is a means to attack the honor or good name of other parties in this case social media such as facebook, instagram, twitter, blog, whatsapp, email and so on. 
Defamation offenses, both regulated in the Criminal Code and the ITE Law, are complaint offenses, which can only be processed by law if a report or complaint is made from the victim of the insulting offense. This is reinforced by the Decision of the Constitutional Court Number: 50/PUU/VI/2008 which states that:

"Article 27 paragraph (3) of the ITE Law cannot be separated from the basic legal norms in Article 310 and Article 311 of the Criminal Code as a genus delict which requires a complaint (klacht) to be prosecuted, must also be treated against acts prohibited in Article 27 paragraph (3) UU ITE, so that Article a quo must also be interpreted as an offense that requires a complaint (klacht) to be prosecuted before the Court."

In determining the existence of insults, content and context are very important parts to understand. The contamination or damage to a person's good name can only be judged by the person concerned. In other words, it is the victim who can subjectively judge what content or part of the Electronic Information or Document he feels has attacked his honor or reputation. The constitution provides protection for the dignity of a person as one of human rights. Therefore, legal protection is given to the victim, and not to other people. Other people cannot judge the same as the victim's judgment. ${ }^{13}$

Meanwhile, context plays a role in providing objective value to the content. Understanding the context includes an overview of the mood of the victim and perpetrator, the intent and purpose of the perpetrator in disseminating information, as well as the interests involved in the dissemination (dissemination) of content. Therefore, to understand the context, expert opinion may be needed, such as linguists, psychologists, and communication experts.

In the context of law enforcement for insulting offenses, it is better if it is carried out using a restorative justice approach in order to produce a winwin solution for the parties without the need to use criminal sanctions against the perpetrator but still provide protection to the victim.

Restorative Justice is a process of resolving cases outside the formal courts. Restorative Justice has a new way of thinking and a new paradigm in viewing a crime committed by a human being without merely giving criminal penalties. Handling of criminal acts can be done by taking into account the wider influence on victims, perpetrators, and the community. The concept of Restorative Justice begins and begins with the understanding

13 Joshua Sitompul. 2018. Pencemaran Nama Baik di Sosial Media Delik Biasa atau Aaduan. from website https://new.hukumonline.com/klinik/detail/ulasan/lt520aa5d4cedab/pencemarannama-baik-di-media-sosial--delik-biasa-atau-aduan/ 
that crime is an act against people or society and is related to the violation/ destruction of an applicable legal norm. ${ }^{14}$

The Characteristics of Restorative Justice according to Muladi: ${ }^{15}$

1. Crime is defined as a person's offense against another and is viewed as a conflict;

2. Focus attention on solving the problem of responsibility and liability for the future;

3. The normative nature is built on the basis of dialogue and negotiation

4. Restitution as a means of repairing the parties, reconciliation and restoration are the main objectives;

5. Justice is formulated as the relationship between rights, assessed on the basis of results;

6. The focus of attention is on repairing the social wounds of crime;

7. The community is a facilitator in the restorative process;

8. The roles of victims and perpetrators are recognized, both in determining problems and in resolving the rights and needs of victims and perpetrators are encouraged to take responsibility;

9. The perpetrator's accountability is formulated as the impact of understanding his actions and is directed to participate in deciding the best;

10. Crime is understood in a comprehensive, moral, social and economic context; and

11. Stigma can be removed through restorative measures

Why a restorative justice approach is needed in dealing with insult cases is due to the fact that according to Treviliana Eka Putri, Research Manager of the Center For Digital Society (CFDS), Faculty of Social and Political Sciences (Fisipol) Universitas Gadjah Mada Yogyakarta (UGM) submitted data from safenet.or id, that the ITE Law criminal cases until October 30, 2020, reached 324 cases. The spirit of the ITE Law is supposed to create a sense of security for everyone in online media, but now the ITE Law has claimed many victims. The reporter has power and the reported person does not have the power like ordinary people and activists. Because the ITE Law will easily criminalize cases of defamation, insult and hate speech. According to

14 Marlina. (2010). Pengantar Konsep Diversi dan Restorative Justice Dalam Hukum Pidana. Medan : USU Press

15 Muladi. 2015. Kapita Selekta Sistem Peradilan Pidana. Semarang : BP Universitas Diponegoro 
Treviliana's records, as many as 172 reported cases came from uploads on Facebook media including Facebook pages. ${ }^{16}$

The problem is, not all those affected by the ITE Law case have evil intentions. It could be because of the lack of digital literacy. Or as a form of social criticism but then interpreted by other parties as insults or hoaxes. So, in a realm that is full of shades of gray, restorative justice needs to be considered so that it doesn't have to all lead to imprisonment. If it is possible to carry out a just peace involving all parties, this needs to be considered as well. Of course, by first making regulations that allow this.

The heart of law is justice. Democracy is cared for by laws that breathe justice. The Pancasila philosophy reflects the basic legal values of justice and democracy. So, when this is passed down by instituting a restorative justice system, at the very least, it can reduce conflicts in the public where there are other ways without having to end up in prison. This is because imprisonment does not always solve the problem if the dose and size are not correct. Mis-institutionalization of the long abolished tradition of revenge in the notion of modern law formation. ${ }^{17}$

Settlement of cases with a restorative justice approach can be carried out at the stage of investigation and investigation, prosecution, even at the stage of examination in court with the following mechanism: ${ }^{18}$

1. In the investigation and investigation stage, based on the provisions in the SE Chief of the National Police Number 8 of 2018 in the event of peace between the complainant and the reported party, the police may terminate the investigation/investigation through a letter of termination of the investigation/investigation and a letter of termination of the investigation/investigation on the grounds of restorative justice.

2. In the prosecution stage, based on the stipulations in the Prosecutor's Office Number 15 of 2020, the public prosecutor offers and seeks peace by summoning the suspect and victim appropriately. The peace

16 Syamsul Azhar. (2020). Pidana di UU ITE Efektif Menjerat Pengguna Medsos, Hingga Oktober Ada 324 Kasus from website https://nasional.kontan.co.id/news/pidana-di-uuite-efektif-menjerat-pengguna-medsos-hingga-oktober-ada-324-kasus

17 Emiral Rangga Tranggono dan R Muhammad Mihradi. (2021). Menggagas Restorative Justice Pada Kasus Hoaxs dan Penghinaan di Dunia Digital from website

https:// bogor-kita.com/menggagas-restorative-justice-pada-kasus-hoaxs-dan-penghinaandunia-digital/

18 Gerald Saratoga Sarayar dan Tasha Kartika Larasati. (2021). Penyelesaian Tindak Pidana Dalam Undang-Undang Informasi dan Transaksi Elektronik Berdasarkan Prinsip Keadilan Restoratif from website https://fjp-law.com/id/penyelesaian-tindak-pidanadalam-undang-undang-informasi-dan-transaksi-elektronik-berdasarkan-prinsipkeadilan-restoratif-restorative-justice/ 
process is carried out voluntarily, with deliberation for consensus, without pressure, coercion and intimidation. In the event that the peace process is reached, the victim and the suspect make a written peace agreement in front of the public prosecutor. If peace is reached, the public prosecutor may terminate the prosecution for reasons of legal interest, and;

3. In the examination stage in court, based on the regulation in Kepdirjenbadilum Number 1691 of 2020, the judge offers and seeks peace between the perpetrator and the victim. If peace is reached, the peace will be included in the consideration of the judge's decision.

Furthermore, in handling criminal acts related to the ITE Law, including insulting offenses through electronic media and or social media, the National Police Chief issued Circular Letter Number: SE/2/II/2021 concerning Ethical Cultural Awareness to Create a Clean, Healthy, and Clean Indonesian Digital Space.

Points 4 (four) to points 9 (Nine) in the Circular Letter contain the following guidelines:

1. In receiving reports from the public, investigators must be able to clearly distinguish between criticism, input, hoaxes, and defamation of goodwill that can be punished for further determining the steps that can be taken;

2. Since receiving the report, so that investigators communicate with the parties, especially the victims (not represented) and facilitate and provide the widest possible space for the disputing parties to carry out mediation;

3. Conduct comprehensive studies and case titles on cases handled by involving Bareskrim/Dittipidsiber (can be through zoom meetings) and make collective decisions based on available facts and data;

4. Investigators have the principle that criminal law is the last resort in law enforcement (ultimum remedium) and prioritizes restorative justice in resolving cases;

5. For the parties and/or victims who will take peaceful steps so that they become part of the priority of investigators for restorative justice to be carried out, except for cases that are potentially divisive, SARA, radicalism and separatism;

6. Victims who still want their case to be brought to court but the suspect has realized and apologized, the suspect is not detained and before the file is submitted to the prosecutor so that space is given again for mediation

Regarding the Circular Letter of the Chief of Police Number 2 of 2021 above, the Chief of Police also issued a Telegram Letter Number: ST/339/II/RES 
1.1.1/2021 which contains guidelines for handling cyber crimes (cyber world) related to the ITE Law. In the telegram it is stated that, a criminal act that can be resolved with the principle of restorative justice is an offense of humiliation based on:

1. Article 27 Paragraph 3 of the ITE Law

2. Articles 207, 310 and 311 of the Criminal Code

It was also stated that no detention was carried out for insulting offenses and could be resolved using a restorative justice approach

\section{Conclusion}

Legal arrangements for defamation offenses in Indonesia are contained in Articles 310, 311, 315, 317, 318, 320, 321 of the Criminal Code and Article 27 Paragraph 3 in conjunction with Article 45 Paragraph 3 of Law Number 16 of 2019 in conjunction with Law Number 112008 concerning Electronic Transaction Information. UU ITE 2008 insult/defamation is an ordinary offense so that it can be processed legally even if there is no complaint from the victim. However, by referring to the Criminal Code as intended by the 2016 UU ITE, the offense turns into a complaint offense (klacht delic) which requires the victim to make a complaint to the authorities.

The restorative justice approach in insulting offenses through social media in accordance with the Pancasila philosophy reflects the basic legal values of justice and democracy. So, when this is passed down by instituting a restorative justice system, at the very least, it can reduce conflicts in the public where there are other ways without having to end up in prison. This is because imprisonment does not always solve the problem if the dose and size are not correct. Mis-institutionalization of the long abolished tradition of revenge in the notion of modern law formation

\section{Acknowledgements}

The author would like to thank the Dean and the staff of the Faculty of Law, Medan Area University for their moral assistance and support in completing this journal. 


\section{References}

\section{Books with an author:}

Eva Achjani Zulfa, 2009. Keadilan Restoratif, Jakarta : Badan Penerbit Fakultas Hukum Universitas

Gomgom TP Siregar. 2020. Suatu Analisis Mengenai Tindak Pidana Pencemaran Nama Baik Melalui Media Elektronik. Bandung : Refika Aditama

Leden Marpaung, 2010. Tindak Pidana Terhadap Kehormatan, Jakarta: Sinar Grafika,

Marlina. 2010. Pengantar Konsep Diversi dan Restorative Justice Dalam Hukum Pidana. Medan : USU Press

Mukti Fajar ND dan Yulianto Achmad. 2010. Dualisme Penelitian Hukum Normatif \& Empiris. Yogyakarta : Pustaka Belajar

Muladi. 2015. Kapita Selekta Sistem Peradilan Pidana. Semarang : BP Universitas Diponegor

Peter Mahmud Marzuki. 2010. Penelitian Hukum, Jakarta : Kencana

R, Soesilo. 1996. Kitab Undang-Undang Hukum Pidana Serta KomentarKomentar Lengkap Pasal Demi Pasal. Bogor : Politeia

Syamsul Arifin. 2011. Falsafah Hukum. Medan : Uniba Pres

S Soekanto, (1995. Penelitian Hukum Normatif suatu tinjauan singkat, Jakarta: Raja Grafindo Persada,

Teguh Prasetyo \& Abdul halim Barkatullah. 2005. Politik Hukum Pidana Kajian Kebijakan Kriminalisasi dan Dekriminalisasi, Yogyakarta : Pustaka Belajar

Zaidan, M. A. 2015. Menuju Pembaharuan Hukum Pidana. Jakarta: Sinar Grafika

\section{Website Material:}

Erizka Permatasari. (2021). Penanganan Pencemaran Nama Baik di Medsos Harus Mengedepankan Restorative Justice. Diakses melalui website https://images.hukumonline.com/frontend/1t5f8445b8eca72/1t5f854ca 34b378.png

Gerald Saratoga Sarayar dan Tasha Kartika Larasati. (2021). Penyelesaian Tindak Pidana Dalam Undang-Undang Informasi dan Transaksi Elektronik Berdasarkan Prinsip Keadilan Restoratif from website https:/ / fjp-law.com/id/ penyelesaian-tindak-pidana-dalam-undangundang-informasi-dan-transaksi-elektronik-berdasarkan-prinsipkeadilan-restoratif-restorative-justice/

Joshua Sitompul. (2018). Pencemaran Nama Baik di Sosial Media Delik Biasa atau Aaduan. Diakses melalui website 
https://new.hukumonline.com/klinik/detail/ulasan/lt520aa5d4cedab / pencemaran-nama-baik-di-media-sosial--delik-biasa-atau-aduan/ Syamsul Azhar. (2020). Pidana di UU ITE Efektif Menjerat Pengguna Medsos, Hingga Oktober Ada 324 Kasus Diakses Melalui https://nasional.kontan.co.id/news/pidana-di-uu-ite-efektif-menjeratpengguna-medsos-hingga-oktober-ada-324-kasus

Emiral Rangga Tranggono dan R Muhammad Mihradi. (2021). Menggagas Restorative Justice Pada Kasus Hoaxs dan Penghinaan di Dunia Digital Diakses Melalui

https:// bogor-kita.com/menggagas-restorative-justice-pada-kasus-hoaxsdan-penghinaan-dunia-digital/

\section{Magazine / Newspaper Articles:}

Barda Nawawi. (1996). Batas-Batas Kemampuan Hukum Pidana Dalam Penanggulangan Kejahatan, Makalah Seminar Nasional Pendekatan Non Penal Dalam Penangulangan Kejahatan, Semarang : Graha Santika Hotel 